\title{
THE
}

$10-2003$

\section{PROTEASE ACTIVITY IN THE PLASMA OF AMERICAN OYSTERS, CRASSOSTREA VIRGINICA, EXPERIMENTALLY INFECTED WITH THE PROTOZOAN PARASITE PERKINSUS MARINUS}

\author{
P. Muñoz \\ University of Rhode Island \\ K. Vance \\ University of Rhode Island \\ M. Gomez-Chiarri \\ University of Rhode Island, gomezchi@uri.edu
}

Follow this and additional works at: https://digitalcommons.uri.edu/favs_facpubs

Terms of Use

All rights reserved under copyright.

\begin{abstract}
Citation/Publisher Attribution
Munoz, P., Vance, K., \& M. Gomez-Chiarri, M. (2003). Protease Activity in the Plasma of American Oysters, Crassostrea virginica, Experimentally Infected With the Protizoan Parasite Perkinsus marinus. Journal of Parasitology, 89(5), 941-951. doi: 10.1645/GE-3126

Available at: http://dx.doi.org/10.1645/GE-3126
\end{abstract}

This Article is brought to you for free and open access by the Fisheries, Animal and Veterinary Sciences at DigitalCommons@URI. It has been accepted for inclusion in Fisheries, Animal and Veterinary Sciences Faculty Publications by an authorized administrator of DigitalCommons@URI. For more information, please contact digitalcommons-group@uri.edu. 


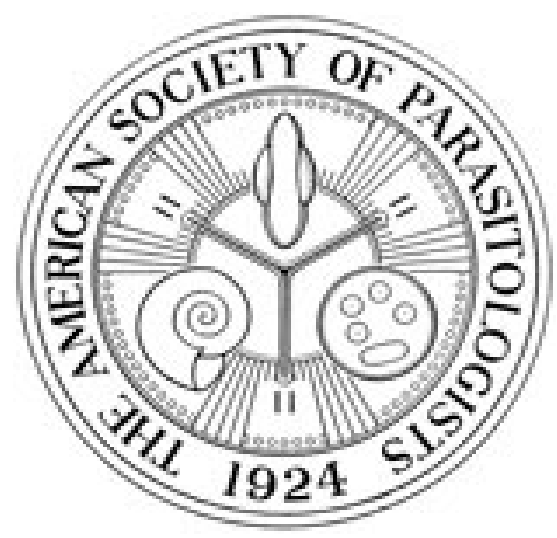

Protease Activity in the Plasma of American Oysters, Crassostrea virginica, Experimentally Infected with the Protozoan Parasite Perkinsus marinus

Author(s): P. Muñoz, K. Vance and M. Gómez-Chiarri

Reviewed work(s):

Source: The Journal of Parasitology, Vol. 89, No. 5 (Oct., 2003), pp. 941-951

Published by: The American Society of Parasitologists

Stable URL: http://www.jstor.org/stable/3285996

Accessed: 04/03/2013 15:12

Your use of the JSTOR archive indicates your acceptance of the Terms \& Conditions of Use, available at http://www.jstor.org/page/info/about/policies/terms.jsp

JSTOR is a not-for-profit service that helps scholars, researchers, and students discover, use, and build upon a wide range of content in a trusted digital archive. We use information technology and tools to increase productivity and facilitate new forms of scholarship. For more information about JSTOR, please contact support@jstor.org.

The American Society of Parasitologists is collaborating with JSTOR to digitize, preserve and extend access to The Journal of Parasitology. 


\title{
PROTEASE ACTIVITY IN THE PLASMA OF AMERICAN OYSTERS, CRASSOSTREA VIRGINICA, EXPERIMENTALLY INFECTED WITH THE PROTOZOAN PARASITE PERKINSUS MARINUS
}

\author{
P. Muñoz ${ }^{\star}$ K. Vance, and M. Gómez-Chiarri† \\ Department of Fisheries, Animal, and Veterinary Science, University of Rhode Island, 23 Woodward Hall, Kingston, Rhode Island 02881. \\ e-mail: gomezchi@uri.edu
}

\begin{abstract}
Perkinsus marinus is responsible for disease and mortality of the American oyster, Crassostrea virginica. To investigate the interactions between $P$. marinus and oyster hemocytes, protease activity was measured in plasma of oysters collected $4 \mathrm{hr}, 24 \mathrm{hr}, 4$ days, and 2 mo after experimental infection with $P$. marinus. A significant increase in protease activity was observed in oyster plasma $4 \mathrm{hr}$ after injection with $P$. marinus, followed by a sharp decrease within $24 \mathrm{hr}$. Gelatin-impregnated gel electrophoresis showed the presence of 2 major bands (60 and $112 \mathrm{kDa}$ ) and 3 less prevalent bands (35, 92, and 200 kDa) with metalloproteinaselike activity in the plasma of noninfected oysters. Additional bands in the 40- to 60-kDa range, corresponding to $P$. marinus serine proteases, were observed in oyster plasma at early time points after infection. A transient, but significant, decrease in the activity of oyster metalloproteinases was observed at early time points after infection. Coincubation of oyster plasma with $P$. marinus extracellular products resulted in a decrease in oyster metalloproteinases and several $P$. marinus proteases. This study provides insights into the role of proteases in the pathogenesis of Dermo disease.
\end{abstract}

Dermo disease caused by the endoparasitic protozoan Perkinsus marinus (Perkinsoa, Noren et al., 1999) is responsible for widespread disease and mortality of the American cupped oyster, Crassostrea virginica, throughout the Gulf of Mexico and the east coast of North America, with correspondingly widespread economic and ecological impact (Ford and Tripp, 1996; Ray, 1996). Infections seem to occur when the parasite, present in the water and encountered as oysters feed, is ingested and crosses the external epithelia of the oyster's mantle, palps, gills, and gut (Dungan et al., 1996; Chintala et al., 2002). This process is probably aided by the release of lytic molecules by $P$. marinus or by being transported in hemocytes that fail to kill the parasite (Mackin, 1951; Mackin and Boswell, 1955; Chintala et al., 2002). The parasite causes a slow-progressing disease, characterized during the final stages by active parasite proliferation and extensive tissue damage, eventually leading to emaciation and death of the oyster (Mackin, 1951; Perkins, 1976).

Proteases have long been recognized as critical factors in disease pathogenesis, immunity, and host-pathogen interactions (Modha et al., 1996; Rhoads and Fetterer, 1997; Nagase and Woessner, 1999; Meza, 2000; Klemba and Goldberg, 2002). Proteases produced by pathogens are involved in the process of infection by inducing parasite differentiation (Rosenthal et al., 1987; Braun-Breton and Pereira, 1988), by facilitating penetration through the host tissues and the release of nutrients (McKerrow et al., 1993), and by stimulating and degrading host proteins involved in immune defenses (McKerrow et al., 1993; Corradin et al., 1999, 2002). Protozoan parasites from species of Perkinsus have been previously shown to secrete extracellular serine proteases in vitro (La Peyre et al., 1995; Faisal, Schafhauser et al., 1999; McLaughlin et al., 2000; Ordás et al., 2001), and extracellular proteins (ECP) from $P$. marinus cells in a culture rich in these serine proteases have been shown to affect oyster defenses in vitro and in vivo (Garreis et al., 1996;

Received 15 November 2002; revised 24 March 2003; accepted 24 March 2003.

* Present address: Departamento de Biología Celular, Facultad de Biología, Universidad de Murcia, 30100 Murcia, Spain.

$\uparrow$ To whom correspondence should be addressed.
Oliver et al., 1999; Tall et al., 1999) and to exacerbate disease in oysters (La Peyre et al., 1996).

Host immune cells are also able to produce a large array of extracellular and intracellular proteases involved in a variety of physiological and pathological processes, including wound healing, signaling, cell migration, cytotoxicity, apoptosis, and necrosis (Fineschi and Miller, 1997; Darmon and Bleackley, 1998; Villadangos et al., 1999; Sim and Laich, 2000). Among host proteases, matrix metalloproteinases (MMPs) are responsible for the maintenance and remodeling of the extracellular matrix, playing an important role in immune-related processes like cell migration and inflammation (Massova et al., 1998; Shapiro, 1998; Nagase and Woessner, 1999). Although relatively few MMPs have been isolated from invertebrates (Wada et al., 1998; Llano et al., 2000), metalloproteinaselike activities have been recently observed in oyster and mussel hemocytes (Mannello et al., 2001; Ziegler et al., 2002). A tissue inhibitor of metalloproteinases (TIMP), which tightly regulates the activity of MMPs, has been recently cloned from the hemocytes of the Pacific oyster, Crassostrea gigas (Montagnani et al., 2001). $\mathrm{Cg}$-TIMP expression is limited to the hemocytes and is upregulated in response to bacterial infection and shell damage, which suggests its involvement in oyster immunity and restructuring of tissues to prevent invasion or repair damage.

The aim of this work was to investigate the profiles and time course of protease activity in oyster plasma at early time points after experimental infection with $P$. marinus, when the host response is vital to the establishment of the parasite. This work may lead to an increase in our understanding of the potential role of proteases in the pathogenesis of Dermo disease.

\section{MATERIALS AND METHODS}

\section{Oysters}

American oysters, C. virginica, $7.6 \pm 1.0 \mathrm{~cm}$ in shell length $(\mathrm{n}=$ 175 per experiment), were purchased from a commercial source (Taylor Shellfish Company, Samish Bay, Washington). These oysters belong to a line resulting from a cross of naturalized $C$. virginica brought from the east coast of the United States to Willapa Bay (Washington) in the early- to mid-1900s and $C$. virginica brought from the east coast during 1980-1990s (J. Davis, pers. comm.). Oysters were placed in groups of $10-15$ oysters in 20-L tanks placed in a recirculating system supplied with $1-\mu \mathrm{m}$-filtered and ultraviolet-irradiated seawater at a temperature 
of $15 \mathrm{C}$, which was slowly increased to $20 \mathrm{C}$ during a period of $2 \mathrm{wk}$. Water salinity and temperature ranged from 25 to $30 \mathrm{ppt}$ and 20 to 25 $\mathrm{C}$ during the course of the experiments. Oysters were fed daily with a mixture of Tetraselmis and Isochrysis $\left(2.5 \times 10^{8}\right.$ cells/day per oyster, Instant Algae ${ }^{(m)}$, Reed Mariculture Inc., San Jose, California). Before experimental infections, a subsample of 25 oysters was tested to assess the presence of $P$. marinus by Ray fluid thiogylocollate medium (RFTM) tissue assay (Ray, 1952, 1966) and polymerase chain reaction (PCR; Marsh et al., 1995) and other infectious conditions by histology (Thoessen, 1994). The intensity of Perkinsus infections was scored according to the method described by Mackin (1962) (Mackin index = $0-5$; e.g., $0=$ no infection and $5=$ heavy infection). The presence of the crustacean parasite Mytilicola intestinalis was observed in the digestive tissue and mantle of 11.3 and $2.4 \%$ of the oysters in the first and second experimental infections, respectively. Noninfected and naturally Dermo-infected American oysters were collected from local sources (Wickford Cove and Dutch Harbor, Rhode Island) (Mareiro, 2002).

\section{Perkinsus marinus cultures}

Perkinsus marinus ATCC 50510 (originally isolated from oysters from Mobjack Bay, Virginia) cultures were maintained as previously described (Gauthier and Vasta, 1993). In brief, Dulbecco modified Eagle medium-Ham F12 (1:1) was dissolved in 23 ppt artificial seawater (ASW) buffered with $25 \mathrm{mM} N$-2-hydroxyethylpiperazine- $N^{\prime}$-2-ethanesulfoninc acid, $7 \mathrm{mM}$ sodium bicarbonate, and supplemented with $100 \mathrm{U} / \mathrm{ml}$ each of penicillin $\mathrm{G}$ and streptomycin sulfate and $2 \%$ fetal bovine serum (Life Technologies Inc., Rockville, Maryland) before filtration through a $0.22-\mu \mathrm{m}$ filter. Cell cultures were maintained at $28 \mathrm{C}$ with weekly changes of media. Cultures in logarithmic growth phase were used in the experimental infections.

\section{Experimental infections}

Two independent experimental infections of oysters with $P$. marinus were carried out in October-December 2000 and July-October 2001 Oyster shells were notched in the edge to make a small hole before parasite inoculation. In the first experiment, oysters were injected with $5 \times 10^{5}$ parasites/g oyster weight diluted in $100 \mu \mathrm{l}$ of filtered ASW (20 ppt) through the hole into the shell cavity using a syringe fitted with a 27-gauge needle. After injection, notches were covered with rubber bands, and inoculated oysters were left out of the water overnight to promote retention of the parasites. Bands were then removed, and oysters were placed in tanks with running seawater until sampling. In the second experiment, $5 \times 10^{6}$ parasites/g oyster weight diluted in $100 \mu$ of ASW were injected into the adductor muscle, and the oysters were returned to the tanks. Control oysters were injected with $100 \mu \mathrm{l}$ of ASW and placed in separate $20-\mathrm{L}$ containers. Mortalities were recorded daily for up to $2 \mathrm{mo}$.

\section{Plasma sample collection and processing}

Twenty oysters from each experimental group (ASW and P. marinus) were shucked and oyster tissues were grossly examined to determine and record the presence of macroscopic parasites or signs of bacterial infection (brown ring or conchiolin deposits; Bricelj et al., 1992), $4 \mathrm{hr}$, $24 \mathrm{hr}, 4$ days, and 2 mo after injection. Hemolymph and fluid contained in the shell cavity (which also contains hemocytes) were collected by aspiration from the pericardial space and from the internal shell volume respectively, using a 27 -gauge needle fitted on a 3-ml syringe. Unless otherwise stated, hemolymph and fluid in the shell cavity were pooled and referred to as hemolymph. Hemolymph samples were placed on ice and centrifuged at $14,000 \mathrm{~g}, 4 \mathrm{C}$, for $10 \mathrm{~min}$. The cell-free supernatan (plasma) was filtered through a 0.2- $\mu \mathrm{m}$ filter (Millipore, Bedford, Massachusetts) and stored at $-20 \mathrm{C}$ until determination of protease activity Samples of rectal tissue were rinsed in ASW to wash off parasites loosely associated with the tissue and used to determine the level of Perkinsus sp. infection by RFTM.

\section{Measurement of total protease activity in plasma}

Proteolytic activity was assayed by the increase of trichloroaceticsoluble azopeptides produced upon incubation of hemolymph with azocasein (Windle and Kelleher, 1997). Azocasein (ICN Biomedicals Inc.,
Costa Mesa, California; $5 \mathrm{mg} / \mathrm{ml})$ was dissolved in Tris- $\mathrm{HCl}(50 \mathrm{mM}$, $\mathrm{pH}$ 8.0) containing $0.04 \%$ sodium azide. One hundred microliters of plasma were incubated with $100 \mu \mathrm{l}$ of azocasein for $30 \mathrm{~min}$ at $37 \mathrm{C}$. The reaction was terminated by the addition of $400 \mu \mathrm{l}$ of $10 \%(\mathrm{w} / \mathrm{v})$ trichloroacetic acid. The precipitated protein was removed by centrifugation $(28,000 \mathrm{~g}$ for $4 \mathrm{~min})$, and the resulting supernatant was transferred to a clean tube containing $700 \mu l$ of sodium hydroxide $(525 \mathrm{mM}$; Fisher Scientific, Swanee, Georgia). Absorbance was measured at 630 $\mathrm{nm}$ on a SpectraMax ${ }^{\circledR} 340$ microplate spectrophotometer system (Molecular Devices, Sunnyvale, California). Negative controls consisted of heat-inactivated plasma samples $(10 \mathrm{~min}$ at $90 \mathrm{C})$. Results are expressed as absorbance at $450 \mathrm{~nm}$ or as units of protease activity per milligram of plasma protein. One unit of protease activity is defined as the amount of enzyme required to produce an increase of 1.0 absorbance at 450 $\mathrm{nm}$. Total plasma proteins were determined using the BioRad Protein assay (BioRad, Hercules, California) based on the Bradford dye-binding procedure (Bradford, 1976) using bovine serum albumin as standard.

\section{Gelatin-impregnated polyacrylamide gel electrophoresis}

Plasma samples collected from oysters in the second experiment (injection into the adductor muscle) were analyzed for profiles of gelatinolytic activity using gelatin-impregnated polyacrylamide gel electrophoresis. Plasma samples (protein concentration, 3-10 $\mu \mathrm{g}$ protein/lane) were mixed 1:1 in nonreducing sodium dodecyl sulfate (SDS) sample buffer (62 mM Tris-HCl, pH 6.8, 2\% SDS, $10 \%$ glycerol, and $0.005 \%$ bromophenol blue), loaded on either SDS gels containing $8 \%$ acrylamide polymerized in the presence of gelatin $(1 \mathrm{mg} / \mathrm{ml}$ ) (Heussen and Dowdle, 1980) or precast $10 \%$ zymogram (gelatin) gels (Novex, Invitrogen, Carlsbad, California), and run on a Xcell II mini cell unit (Novex) on constant current. After electrophoresis, gels were incubated in $2.5 \%$ Triton X-100 or zymogram renaturing buffer (Novex) for $1 \mathrm{hr}$ to restore proteolytic activity, rinsed twice in phosphate-buffered solution (PBS, pH 7.4), and incubated overnight in PBS or zymogram developing buffer (Novex) at $37 \mathrm{C}$ to allow proteolysis. The gels were stained in a $0.1 \%$ solution of amido black in methanol-acetic acidwater (40:10:50\%) for $1 \mathrm{hr}$ and destained in the same solvent. Proteases were observed as clear bands in a blue background wherever digestion of copolymerized gelatin occurred. Pictures were taken and analyzed using Kodak electrophoresis documentation and analysis system 120 (Eastman Kodak, Rochester, New York). Results are expressed as ratio between the band intensity (relative object intensity) as determined by densitometry and concentration of protein loaded in the gels in micrograms. Selected samples were concentrated using microfuge concentrators with a membrane cutoff of $10 \mathrm{kDa}$, according to manufacturer's instructions (Microcon-10, Amicon Inc.; Millipore). Approximate molecular weights of denatured nonreduced proteases in gelatin-impregnated gels were estimated by comparison of clear bands of activity with prestained molecular weight markers (Broad range, BioRad) and by visual comparison with band patterns observed in previously published research (Faisal, Oliver et al., 1999; Faisal, Schafhauser et al., 1999; Ziegler et al., 2002).

The effect of protease inhibitors on gelatinolytic activity was determined by incubating gels overnight at $37 \mathrm{C}$ in PBS containing 1 of the following inhibitors: $10 \mathrm{mM} o$-phenantroline dissolved in dimethyl sulfoxide, $10 \mathrm{mM}$ phenylmethylsulphonyl fluoride (PMSF) dissolved in ethanol, or 10 or $100 \mathrm{mM}$ ethylenediaminetetraacetic acid (EDTA) dissolved in water.

\section{Effect of coincubation with Perkinsus ECP on oyster plasma gelatinolytic activity}

Plasma samples of 4 oysters from Wickford Cove, Rhode Island (average Mackin index $2.3 \pm 1.5$ ), were pooled, mixed $1: 1$ with $20 \mu \mathrm{l}$ of ECP (protein concentration of $0.5 \mathrm{mg} / \mathrm{ml}$ and protease activity of $10 \mathrm{U} /$ mg of protein) from cultures of Perkinsus-1 (P-1; Oliver et al., 1999), and incubated for $1 \mathrm{hr}$ at room temperature with gentle agitation. Twenty-microliter samples from a pool of plasma (protein concentration of $0.6 \mathrm{mg} / \mathrm{ml}, 4 \mathrm{U} / \mathrm{mg}$ protein) from an additional 4 oysters from Dutch Harbor (Rhode Island; average Mackin index of 0 ) were incubated with $20-\mu 1$ serial dilutions $(1: 2$, starting concentration of $0.04 \mathrm{mg} / \mathrm{ml}, 1 \mathrm{U} /$ $\mathrm{mg}$ protein) in 9 salts solution (NSS) (Marden et al., 1985) of a fraction of ECP containing low-molecular weight (LMW) proteins. Samples were then run in a gelatin-impregnated $8 \%$ SDS-polyacrylamide gel 
TABLE I. Prevalence (\%) and average intensity (Mackin index, MI) of Perkinsus infection in oysters injected with artificial seawater (ASW) or P. marinus cells.

\begin{tabular}{|c|c|c|c|c|c|c|c|c|}
\hline \multirow[b]{3}{*}{ Experiment no. } & \multicolumn{8}{|c|}{ Time after experimental infection } \\
\hline & \multicolumn{2}{|c|}{$4 \mathrm{hr}$} & \multicolumn{2}{|c|}{$24 \mathrm{hr}$} & \multicolumn{2}{|c|}{4 days } & \multicolumn{2}{|c|}{$2 \mathrm{mo}$} \\
\hline & $\begin{array}{c}\text { Prevalence } \\
(\%)\end{array}$ & $\mathrm{MI}(\mathrm{SD})^{*}$ & $\begin{array}{c}\text { Prevalence } \\
(\%)\end{array}$ & $\mathrm{MI}(\mathrm{SD})$ & $\begin{array}{c}\text { Prevalence } \\
(\%)\end{array}$ & MI (SD) & $\begin{array}{c}\text { Prevalence } \\
(\%)\end{array}$ & MI (SD) \\
\hline \multicolumn{9}{|l|}{1} \\
\hline ASW & 0 & 0 & 0 & 0 & 0 & 0 & 0 & 0 \\
\hline P. marinus & 55 & $0.7(0.1)$ & 50 & $0.7(0.2)$ & 35 & $0.6(0.1)$ & 20 & $0.2(0.1)$ \\
\hline \multicolumn{9}{|l|}{2} \\
\hline ASW & 0 & 0 & 0 & 0 & 0 & 0 & 0 & 0 \\
\hline P. marinus & 100 & $2.3(0.2)$ & 100 & $3.5(0.3)$ & 100 & $3.3(0.2)$ & 100 & $0.3(0.6) \dagger$ \\
\hline
\end{tabular}

* Infections were evaluated using Ray fluid thiogylocollate medium tissue assay, and the intensity of infection in each oyster was scored using MI, which ranges from 0 (no infection) to 5 (heavy infection). $\mathrm{n}=20$ oysters per group and time point.

$\dagger \mathrm{n}=14$ oysters.

electrophoresis (PAGE) and processed as described above. LMW ECP was prepared by passing $100 \mu \mathrm{l}$ of ECP through Microcon-50 concentrators (Amicon). The filtrate containing proteins less than $50 \mathrm{kDa}$ was concentrated using Microcon-10 concentrators.

\section{Effect of method of hemolymph sample collection on pattern of gelatinolytic activity}

Naturally infected oysters from Wickford Cove (average Mackin in$\operatorname{dex} 2.3 \pm 1.5$ ) were divided into 2 groups of 5 oysters each and notched in the shell. Hemolymph and shell cavity fluid were collected either through the notch in the shell or after shucking by aspiration from the pericardial space and from the internal shell volume, respectively, using a 27-gauge needle fitted on a 1-ml syringe. Hemolymph samples were placed on ice and centrifuged at $14,000 \mathrm{~g}, 4 \mathrm{C}$, for $10 \mathrm{~min}$. The cellfree supernatant (plasma) from 5 oysters was pooled, filtered through a $0.2-\mu \mathrm{m}$ filter, and stored at $-80 \mathrm{C}$ until determination of protease activity. Hemocytes were resuspended in $100 \mu \mathrm{l}$ of NSS, homogenized, centrifuged at $14,000 \mathrm{~g}, 4 \mathrm{C}$, for $10 \mathrm{~min}$, and lysate supernatants were pooled and stored at $-80 \mathrm{C}$. For determination of the pattern of gelatinolytic activity, samples were concentrated using Microcon-10 concentrators, run in a gelatin-impregnated $10 \%$ SDS-PAGE, and processed as described above.

\section{Statistics}

Statistical analysis was performed using Sigma Stat ${ }^{\circledR}$ software (SPSS Science, Chicago, Illinois). Total protease activity data were analyzed using 2-way analysis of variance (ANOVA). Post-hoc Tukey tests were conducted where significance $(P<0.05)$ was detected. Densitometric levels of gelatinolytic activity were analyzed using a 3-way ANOVA with infection (noninfected and infected), time, and band size (molecular weight) as variables. Multiple comparison procedures (Mann-Whitney rank sum tests or Student's $t$-test) were used to isolate significant groups. Linear regression was used to analyze potential relationships between protease activity and infection intensity and relationships between different bands.

\section{RESULTS}

\section{Experimental infections with Perkinsus marinus}

Prevalence of $P$. marinus ranged from $20 \%$ (first experiment) to $100 \%$ (second experiment) (Table I). Whereas no mortality was observed in the first experiment, oysters in the second experimental infection reached a cumulative mortality of $30 \%$ by 2 mo after injection. No $P$. marinus infection was observed in control oysters by either PCR or RFTM. Although the intensity of Dermo infection was similar in both experiments 2 mo after injection (Table I), there was a significant difference between levels of infection between the 2 experiments at earlier time points after injection. Moreover, quantification of $P$. marinus in the hemolymph of selected oysters collected $6 \mathrm{wk}$ after injection of the parasite in the adductor muscle (second experiment) showed a Mackin index of $2.1 \pm 1.2$ (indicative of moderate infections), suggesting that oyster mortalities occurring between 15 and 60 days after injection of the parasite were due to heavy $P$. marinus infections.

\section{Total protease activity in plasma of experimentally infected oysters}

Total protease (caseinolytic) activity was observed in the plasma of both control and experimentally infected oysters (Fig. 1). Significantly higher levels of protease activity were observed in the plasma of oysters injected with $P$. marinus $4 \mathrm{hr}$ after experimental infection (Fig. 1). There was no significant difference in plasma protease activity $24 \mathrm{hr}$ or 4 days after injection into the shell cavity of either ASW or $P$. marinus (first experiment, Fig. 1a). However, significantly lower levels of protease activity $(P<0.05)$ were observed in the plasma of oysters collected $24 \mathrm{hr}$ after injection of $P$. marinus into the adductor muscle (second experiment, Fig. 1b).

\section{Gelatinolytic activity in plasma of experimentally infected oysters}

The patterns of bands with gelatinolytic activity were highly variable between individual oysters. However, differences could be observed between experimental groups at the different time points (Figs. 2, 3; Table II). Bands with gelatinolytic activity of approximate molecular weights of $35,60,92,112$, and 200 $\mathrm{kDa}$ were observed in the plasma of oysters injected in the adductor muscle with filtered ASW (Fig. 2). The most prevalent bands were an intense and broad band of approximately $60 \mathrm{kDa}$ and a band of $112 \mathrm{kDa}$ (Table II). A 35-kDa band, a sharp 92$\mathrm{kDa}$ band, and a faint band of $200 \mathrm{kDa}$ were observed in the plasma of a small proportion of oysters (Fig. 2, lane 1; Table II). Injection of $P$. marinus elicited additional LMW bands (44to 53-kDa range) in oyster plasma as early as $4 \mathrm{hr}$ after injection (Table II). The LMW bands were most prevalent $24 \mathrm{hr}$ and 4 days after injection with $P$. marinus (Fig. 3). A slight upward 

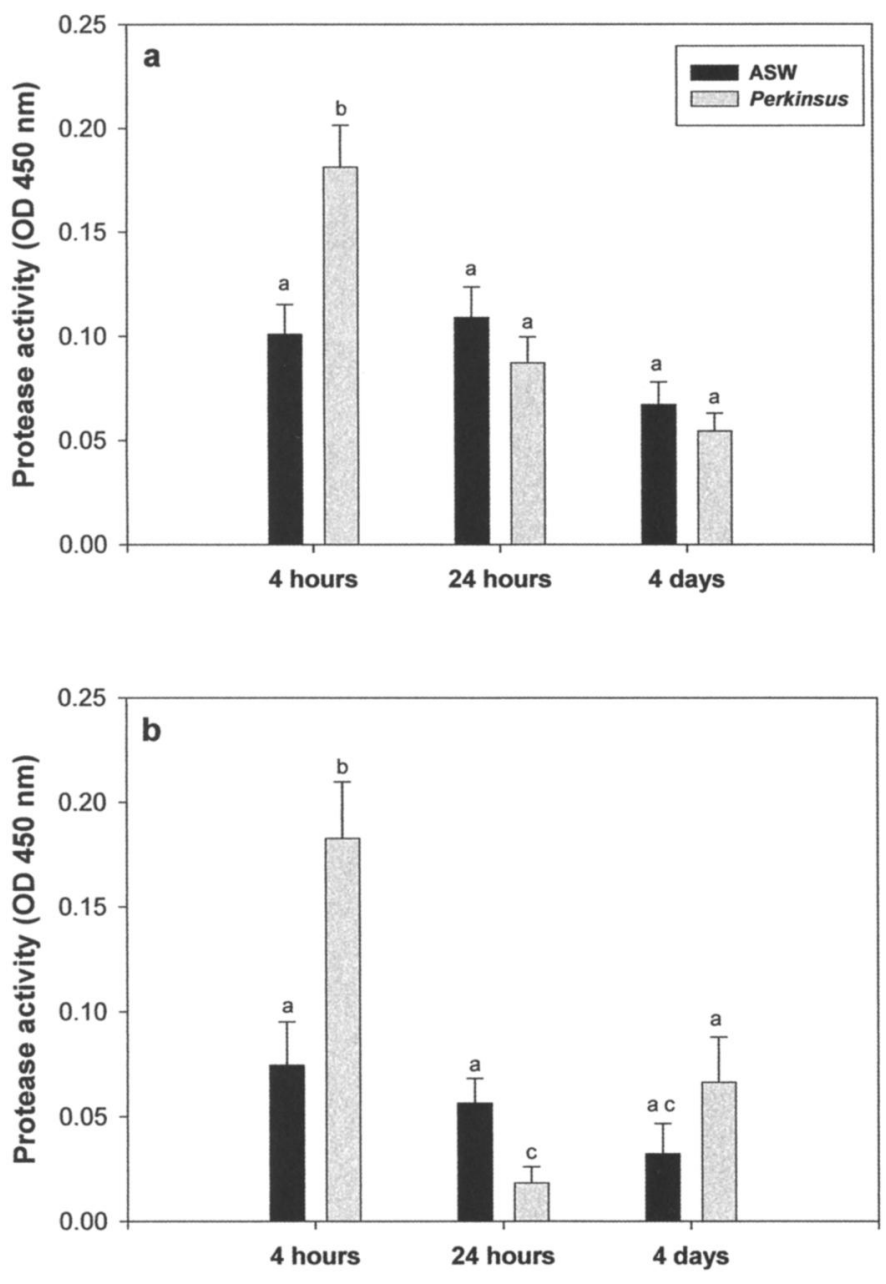

Time after injection

FIGURE 1. Total protease activity in plasma of oysters injected with filtered artificial seawater (ASW) or Perkinsus marinus (Perkinsus). a Protease activity in plasma of oysters that were injected in the shell cavity (first experiment). b. Protease activity in plasma of oysters that were injected in the adductor muscle (second experiment). Protease activity in the plasma of at least 5 oysters per group and per experiment was determined using the azocasein assay. Results are expressed as average \pm standard error of mean $O_{450 \mathrm{~nm}}$. Same letter indicates no statistical significance.

shift in the molecular weight of the $60-\mathrm{kDa}$ band (Fig. 3b, lanes $1,2)$ and the presence of 1 or 2 additional bands in the 57- to 62-kDa range were also observed in the plasma of several oysters injected with $P$. marinus (Fig. 3b, lanes 3-8). An overall increase in the prevalence of the 35-, 112-, and 200-kDa bands was observed in plasma of oysters injected with $P$. marinus (Table II). Oysters collected 2 mo after injection of $P$. marinus showed patterns of protease activity similar to oysters injected with ASW (Table II).

The 112-kDa band was not inhibited with the serine protease inhibitor PMSF $(10 \mathrm{mM})$ or the metalloprotease inhibitors EDTA $(10 \mathrm{mM})$ and $o$-phenantroline $(10 \mathrm{mM})$. The $60-\mathrm{kDa}$ band was partially inhibited with the metalloprotease inhibitors $o$-phenantroline $(10 \mathrm{mM})$ and EDTA $(10 \mathrm{mM})$. Total inhibition of the $35-\mathrm{kDa}$ band, as well as partial inhibition of the 60 - and
112-kDa bands, was detected after incubation of the gels with $100 \mathrm{mM}$ EDTA. LMW proteases (40-50 kDa) were inhibited with $10 \mathrm{mM}$ PMSF (data not shown).

Densitometric analysis of the intensities of the 60- and 112$\mathrm{kDa}$ bands with gelatinolytic activity in plasma of oysters injected with ASW showed significantly higher levels of these proteases 4 and $24 \mathrm{hr}$ after injection, as compared with levels measured at later time points, suggesting that the stress of injection or shell damage could induce the activation of oyster proteases (Fig. 4a). However, significantly lower levels of activity of the 60 - and 112-kDa bands were observed in the plasma of oysters collected $4 \mathrm{hr}$ after injection $P$. marinus (Fig. 4). Low levels of the $60-\mathrm{kDa}$ protease persisted $24 \mathrm{hr}$ after injection of $P$. marinus. No difference in the intensity of the 60- and $112-\mathrm{kDa}$ bands was observed in the plasma of oysters injected with either ASW or $P$. marinus 4 days and 2 mo after injection. No significant correlation was observed between levels of protease activity for the 60 - and 112-kDa bands or between band intensity and intensity of $P$. marinus infection (data not shown).

\section{Effect of Perkinsus ECP on the activity of oyster plasma proteases}

Coincubation of pools of plasma from noninfected or naturally infected $C$. virginica with $P$. marinus ECP or a LMW (less than $50 \mathrm{kDa}$ ) fraction of $P$. marinus ECP resulted in a dosedependent decrease in the intensity of the $60-$ and $112-\mathrm{kDa}$ oyster proteases (Fig. 5, lanes 6-8). The incubation of oyster plasma with $P$. marinus ECP also resulted in a change in the gelatinolytic profile of the ECP, causing a decrease in the intensity of bands in the $80-$ to $100-\mathrm{kDa}$ range (Fig. 5, lane 3).

\section{Effect of method of hemolymph sample collection on pattern of gelatinolytic activity}

The patterns of gelatinolytic activity in pools of plasma from noninfected (Dutch Harbor; Fig. 5) and plasma and lysates of hemocytes from naturally infected (Wickford Cove, Mackin in$\operatorname{dex} 2.3 \pm 1.5$; Figs. 5, 6) C. virginica from Rhode Island were similar to the patterns observed in the plasma of $C$. virginica used in the experimental infections (Samish Bay, Washington; Figs. 2, 3). Bands of 35, 60, and $112 \mathrm{kDa}$ were observed in noninfected oysters, whereas additional bands in the 40- to 53$\mathrm{kDa}$ range were observed in the plasma and hemocyte lysates of naturally infected oysters (Fig. 6). Method of hemolymph sampling (aspiration through notch vs. shucking) did not appear to affect the profile of protease activity (Fig. 6).

\section{DISCUSSION}

Although the drastic conditions of experimental infections do not reproduce the natural route of exposure to pathogens, these experiments have proven useful in the study of host-pathogen interactions and mechanisms of disease resistance (Druilhe et al., 2002). In this study, the availability of in vitro cultures of $P$. marinus- and Perkinsus sp.-free susceptible oysters has allowed us to investigate the role of proteases in early infection, when parasite and host come in contact for the first time. Although the virulence of $P$. marinus is severely diminished when the parasite is cultured (Ford et al., 2002), we were able to establish successful infections in 1 of the 2 experiments per- 


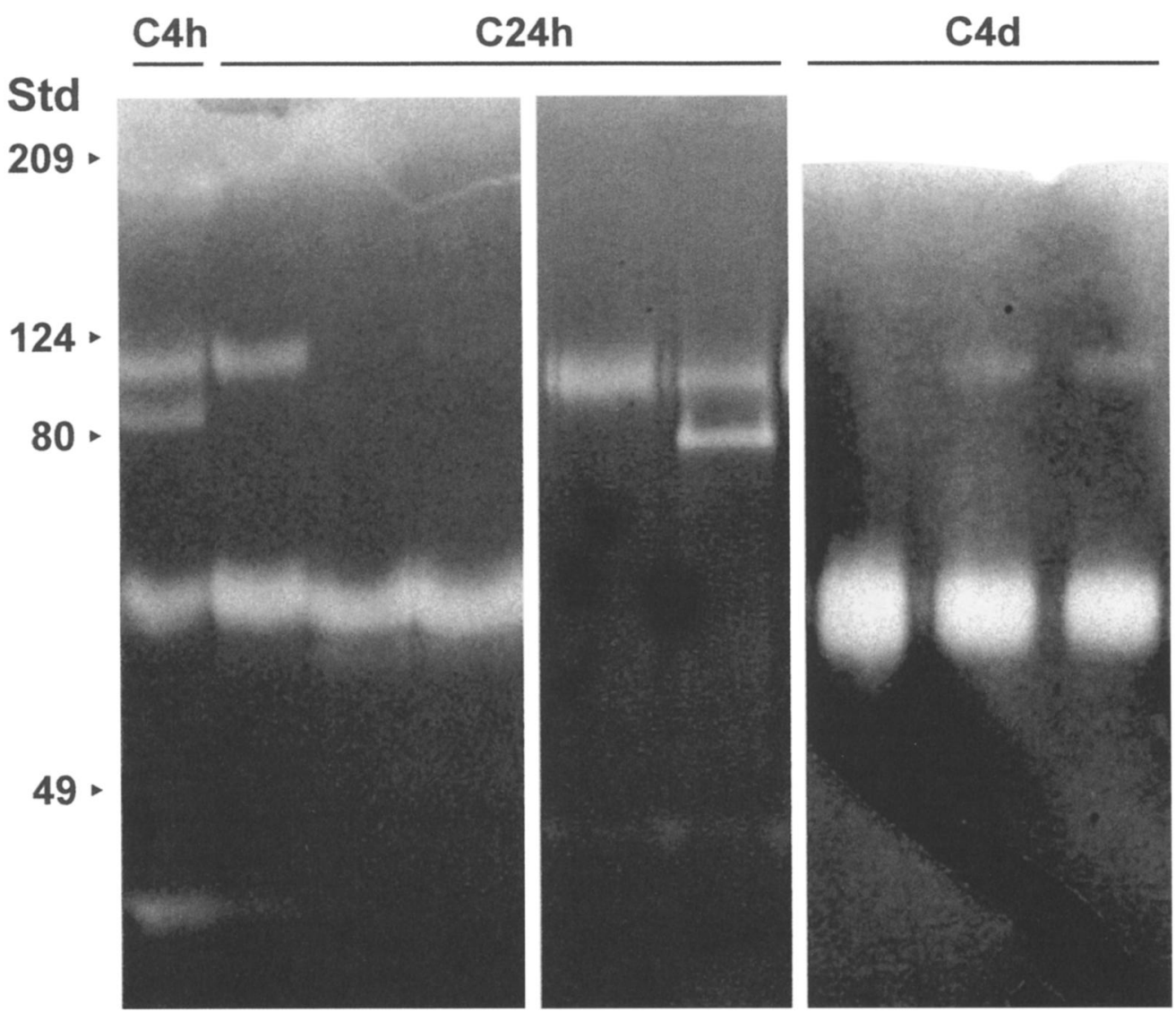

FIGURE 2. Representative patterns of gelatinolytic activity in the plasma (5-10 $\mu \mathrm{g}$ protein/lane) in control oysters (C) collected $4 \mathrm{hr}$, $24 \mathrm{hr}$, and 4 days after injection in the adductor muscle with filtered artificial seawater (ASW). Bands of activity are shown as clear bands over a dark background.

formed in this study. The different outcomes from the 2 experimental infections may have been due to differences in the method of challenge (injection into the shell cavity vs. injection in the adductor muscle), the dose of the parasite, or the metabolic condition of oysters at the time of challenge (Chintala et al., 2002). Nevertheless, differences in the profile of protease production between the successful and unsuccessful experimental infections provide clues to the role of proteases in the pathogenesis of Dermo disease.

Successful experimental infection with $P$. marinus resulted not only in an increase in protease activity in oyster plasma as soon as $4 \mathrm{hr}$ after injection but also in the appearance of LMW bands of gelatinolytic activity. We have also observed the presence of LMW protease bands in the plasma of naturally infected oysters. The fact that these bands of protease activity are seen only in infected oysters, the similarity to band patterns observed in the analysis of supernatants of $P$. marinus in culture (La Peyre et al., 1995; Faisal, Schafhauser et al., 1999), and the inhibition pattern consistent with their nature as serine proteases indicate that these LMW proteases are most probably produced by the parasite. This is, to our knowledge, the first report of the detection of $P$. marinus serine proteases in the plasma of either experimentally or naturally infected oysters. The expression of $P$. marinus antigens in vivo has been studied using polyclonal antibodies to $P$. marinus ECP, but the nature of these parasitic antigens is unknown (Ottinger et al., 2001). An increase with time in the intensity of bands with metalloproteaselike activity has been previously observed in the plasma of oysters collected biweekly after experimental infection with $P$. marinus (Faisal, Oliver et al., 1999), but this study failed to detect the presence of LMW serine proteases. Lack of detection could be attributed to limits in the sensitivity of substrate-impregnated gel electrophoresis, which, in our experience, does not detect protease activity in oyster plasma unless at least $10 \mu \mathrm{g}$ of plasma protein is loaded in the gels. Our success in detecting LMW serine proteases in the plasma of experimentally and naturally infected oysters could be because of the large amounts of parasites that were injected into the adductor muscle and the high concentrations of sample loaded in the gels. Interestingly, we failed to detect any of the high-molecular weight (HMW, more than 60 kDa) bands characteristic of $P$. marinus ECP (Faisal, Schafhauser et al., 1999; MacIntyre et al., in press). Differences in the patterns of parasitic protease activity in vivo and in vitro could be due to (1) differences in the profiles of protease activity between different $P$. marinus isolates, (2) proteolytic degradation of HMW parasitic proteases by oyster proteases, resulting in the appearance of bands of lower molecular weight, (3) induction of changes in the profiles of parasitic protease activity in the presence of oyster plasma, resulting in activation of LMW parasitic proteases and downregulation of HMW parasitic proteases, or (4) selective inhibition of the activity of HMW parasitic proteases by factors present in oyster plasma. 


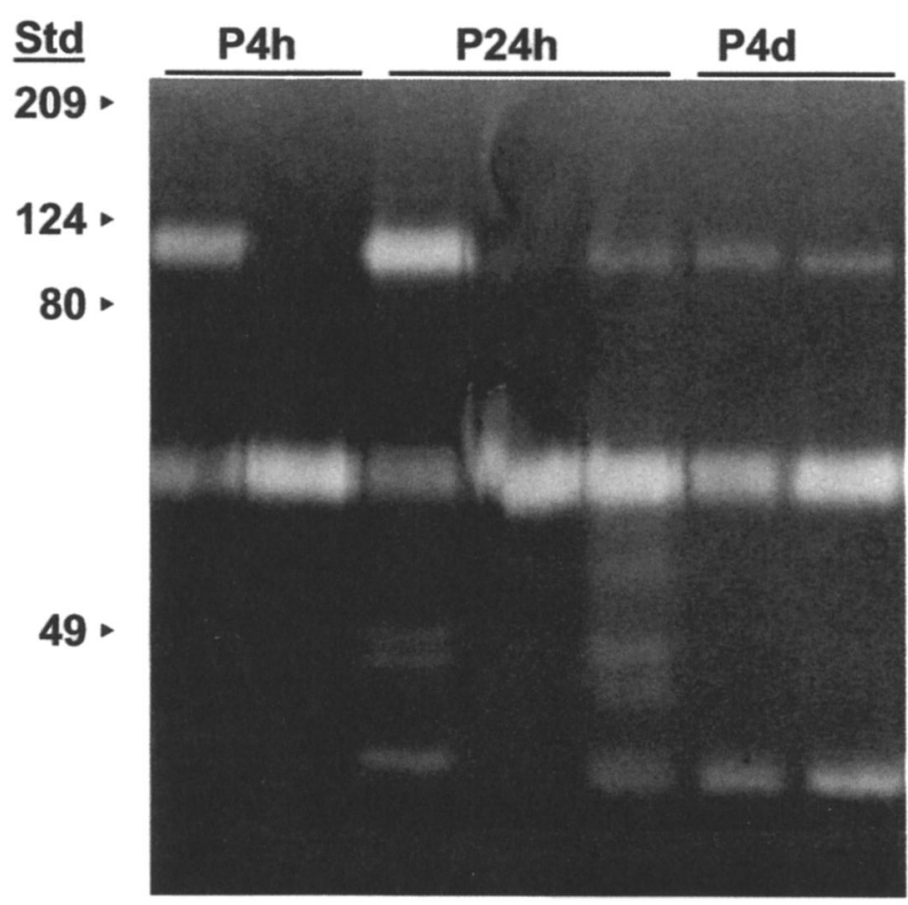

a

b

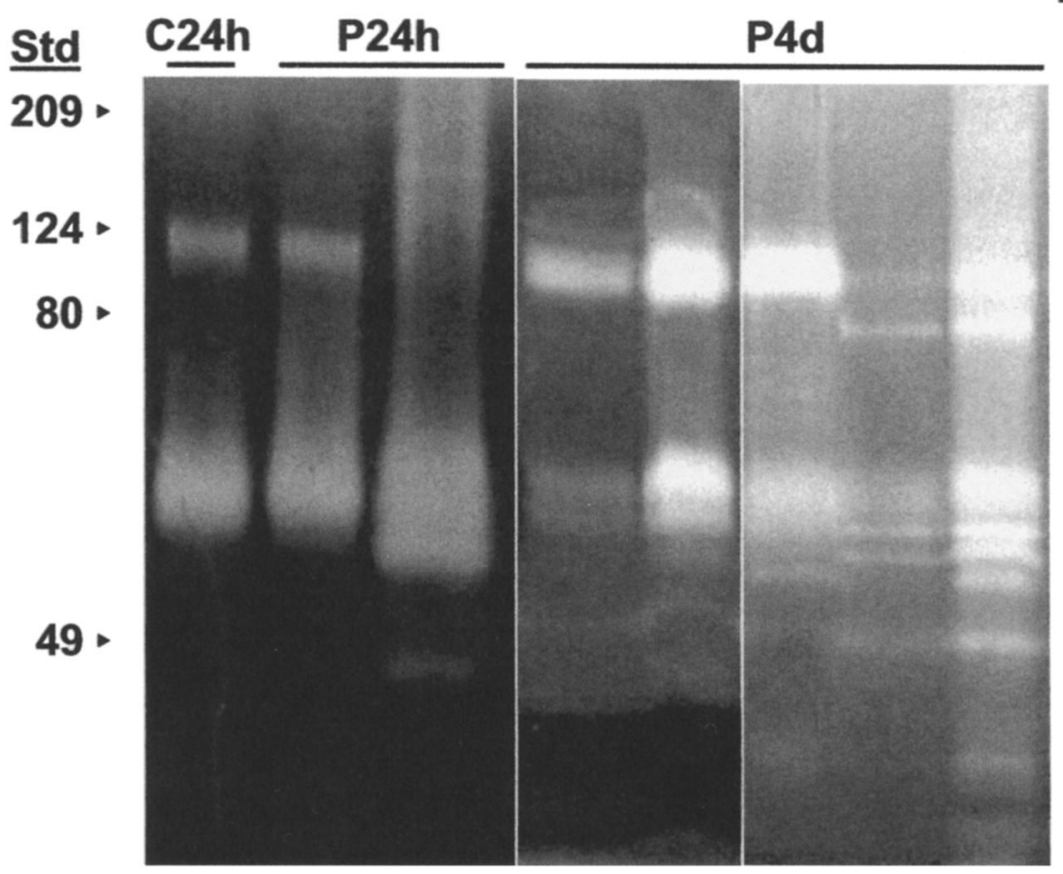

FIGURE 3. Representative patterns of gelatinolytic activity in the plasma (5-10 $\mu \mathrm{g}$ protein/lane) of oysters collected $4 \mathrm{hr}$, $24 \mathrm{hr}$, and $4 \mathrm{days}$ after injection in the adductor muscle with Perkinsus marinus (P) or ASW (C). Bands of activity are shown as clear bands over a dark background. Lanes 7 and 8 correspond to the same sample run at 2 different concentrations ( 3 and $10 \mu \mathrm{g}$ protein/lane, respectively).

Profiles of proteolytic activity have been shown to be dependent on the Perkinsus species and isolate and vary significantly depending on culture conditions (McLaughlin et al., 2000; MacIntyre et al., 2003). For example, whereas $P$. marinus isolate $\mathrm{P}-1$ produces an array of LMW and HMW proteases, other $P$. marinus isolates have been shown to predominantly produce LMW proteases in vitro (C. Earnhart, pers. comm.). However, our in vitro experiments also showed that coincubation of oyster plasma with the ECP of $P$. marinus (P-1) results in a selective decrease in the intensity of several parasitic HMW proteases $(80-100 \mathrm{kDa})$, suggesting the presence of factors in the plasma of $C$. virginica that could selectively inhibit or cause the degradation of parasitic proteases. Our results are also consistent with the recent findings of MacIntyre et al. (2003), which 
TABLE II. Percentage of oyster plasma samples in which each band $(\mathrm{kDa})$ of gelatinolytic activity was observed.

\begin{tabular}{|c|c|c|c|c|c|c|c|c|}
\hline \multirow{2}{*}{$\begin{array}{c}\text { Experimental } \\
\text { group }\end{array}$} & \multicolumn{8}{|c|}{ Percentage of band occurrence $\ddagger$} \\
\hline & 200 & 112 & 92 & 60 & 53,51 & 46 & 44 & 35 \\
\hline \multicolumn{9}{|l|}{ ASW* } \\
\hline $4 \mathrm{hr}(5) \dagger$ & 17 & 100 & 40 & 100 & - & - & - & 17 \\
\hline $24 \mathrm{hr}(6)$ & - & 83 & 17 & 100 & - & - & - & - \\
\hline 4 days (6) & - & 67 & 17 & 100 & - & - & - & 33 \\
\hline 2 mo (3) & - & 100 & - & 100 & - & - & - & - \\
\hline \multicolumn{9}{|c|}{ Perkinsus marinus* } \\
\hline $4 \mathrm{hr}(7)$ & - & 57 & - & 100 & 14 & 29 & - & 29 \\
\hline $24 \mathrm{hr}(11)$ & 18 & 100 & 45 & 100 & 27 & 73 & 18 & 64 \\
\hline 4 days (9) & 22 & 100 & 22 & 100 & 11 & 22 & 11 & 44 \\
\hline 2 mo (3) & - & 100 & - & 100 & - & - & - & 33 \\
\hline
\end{tabular}

* Oysters were injected in the adductor muscle with either artificial seawater (ASW) or P. marinus cells.

$\uparrow$ Time after injection (number of oysters tested).

$\ddagger$ - Indicates $0 \%$.

showed that supplementation of $P$. marinus cell cultures with fresh plasma from $C$. virginica induces a change in the profile of protease activity in $P$. marinus P-1 ECP, resulting in the appearance of LMW proteases and a decrease in the activity of several HMW proteases. The appearance of LMW proteases in $P$. marinus ECP supplemented with $C$. virginica plasma was not because of activation of oyster proenzymes or modification of HMW proteases or inactive proteases, suggesting the selective induction of de novo LMW parasitic proteases by factors present in oyster plasma (MacIntyre et al., 2003).

This research also describes the effect of experimental infection with $P$. marinus on the activity and profile of oyster plasma proteases. Little is known about the role of host proteases in the response of oyster hemocytes against infection. Ziegler et al. (2002) recently characterized a 68-kDa MMP-like enzyme, as well as the presence of 2 additional bands of proteolytic activity of approximately 40 and $100 \mathrm{kDa}$, in the lysate of hemocytes from $C$. virginica. Bands of metalloproteaselike activity of $51,60,77$, and $119 \mathrm{kDa}$ have been reported in the plasma of noninfected C. virginica (Faisal, Oliver et al., 1999; Faisal, Schafhauser et al., 1999). The presence of 2 additional bands of about 138 and $220 \mathrm{kDa}$ was observed in plasma of oysters collected from 2 to $10 \mathrm{wk}$ after experimental infection with $P$. marinus (Faisal, Oliver et al., 1999). Our comprehensive evaluation of the profiles of gelatinolytic activity in the plasma of a large number of noninfected and infected $C$. virginica showed the presence of bands of metalloproteinaselike activity of approximately $35,60,92,112$, and $200 \mathrm{kDa}$ in the plasma of $C$. virginica. Considering differences in methodology between the different studies, as well as the inaccuracy inherent to the estimation of molecular weights in gelatin-impregnated SDSPAGE gels (Martinez and Cazzulo, 1992; Faisal, Schafhauser et al., 1999), we hypothesize that the 60-, 112-, and 200-kDa proteases detected in our study correspond to the 60-, 119- or 138-, and 220-kDa proteases from Faisal, Oliver et al. (1999). The bands of gelatinolytic activity at about 40,68 , and $100 \mathrm{kDa}$ observed by Ziegler et al. (2002) could correspond to the 35-, $60-$, and 112-kDa bands detected in this study. The additional sharp $92-\mathrm{kDa}$ band detected for the first time in our study is
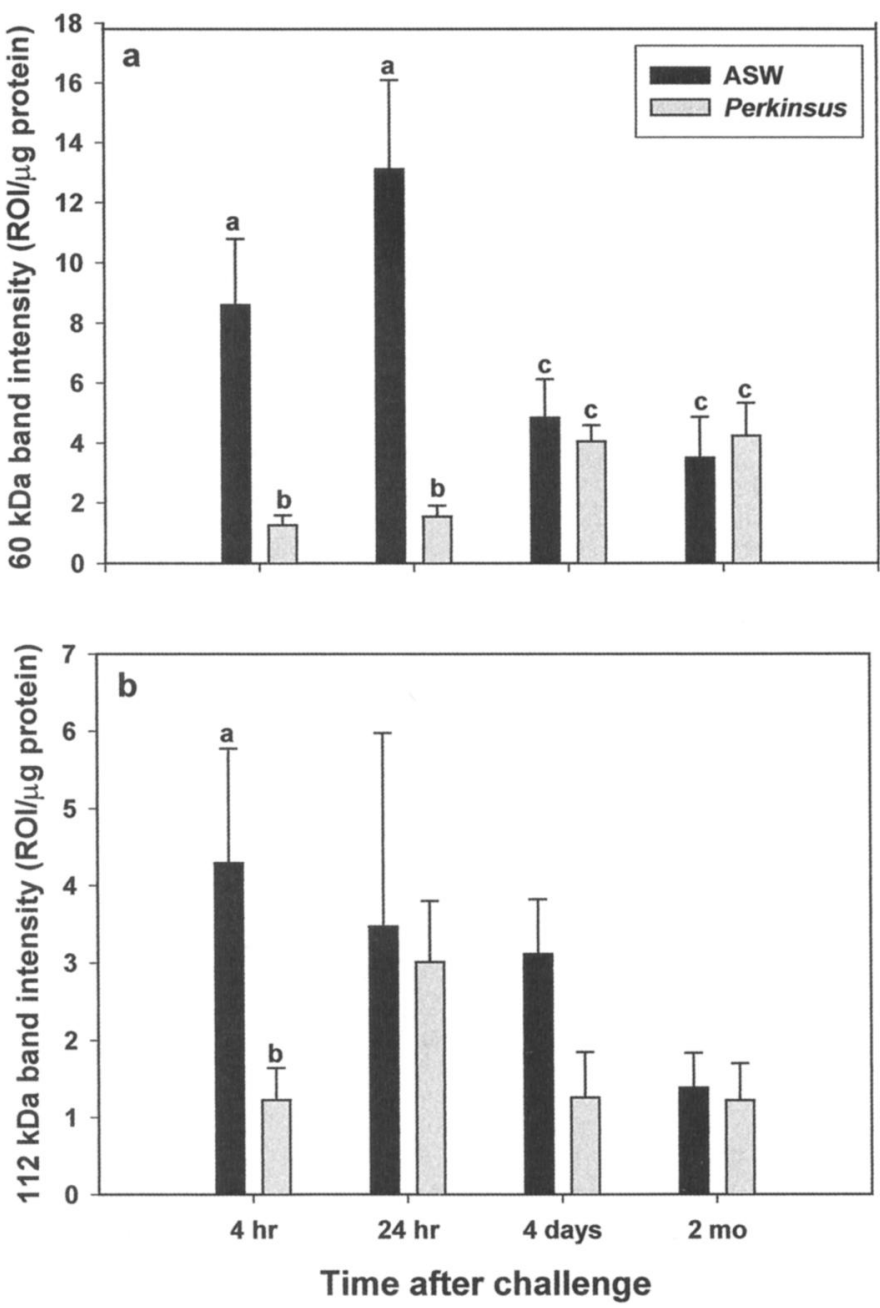

FIGURE 4. Densitometric analysis of the intensity of selected bands with gelatinolytic activity in the plasma of oysters collected at different time points after injection in the adductor muscle with filtered artificial seawater (ASW) or Perkinsus marinus (Perkinsus). a. Intensity of the $60-\mathrm{kDa}$ band. b. Intensity of the 112-kDa band. Results are expressed as average \pm standard error of mean relative object intensity units per microgram of plasma protein loaded in the gel of at least 5 oysters per experimental group.

detected in only $22 \%$ of the oysters, which may explain why it has not been previously observed in other research (Faisal, Oliver et al., 1999; Faisal, Schafhauser et al., 1999; Ziegler et al., 2002). Whereas 2 distinct bands of 51 and $60 \mathrm{kDa}$ were observed in both noninfected and infected oysters in previous research (Faisal, Oliver et al., 1999), we observed only 2 distinct bands in the 57 - to $60-\mathrm{kDa}$ range in infected oysters. Although incomplete inhibition of the broad $57-$ to $60-\mathrm{kDa}$ band by metalloprotease inhibitors suggests the presence of several proteases of differing nature, incomplete inhibition could be also due to technical difficulties in inhibiting large amounts of proteases in substrate-impregnated gels.

It is also unclear if any of the bands with metalloproteinaselike activity detected in $C$. virginica plasma correspond to products of proteolytic degradation. Although the increase in the prevalence of the $35-\mathrm{kDa}$ band in oysters infected with $P$. marinus ( $47 \%$ vs. $20 \%$ in control oysters) is concurrent with a decrease in the intensity of the $60-$ and $112-\mathrm{kDa}$ bands, no 


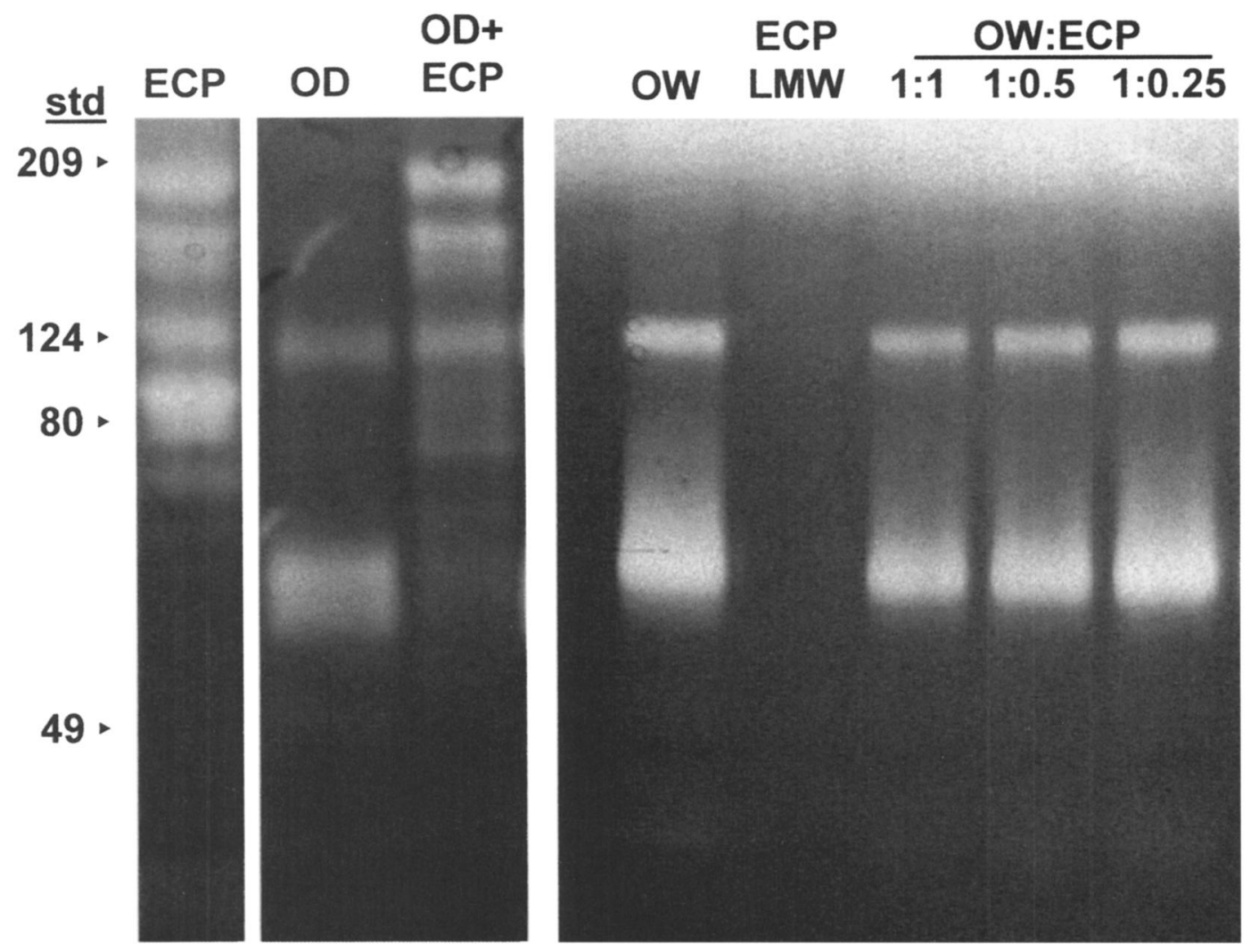

FIGURE 5. Effect of coincubation of oyster plasma with Perkinsus ECP on the pattern of gelatinolytic activity. ECP = P-1 extracellular proteins; $\mathrm{OW}=$ plasma from naturally infected oysters (Mackin index $2.3 \pm 1.5$ ); OD = plasma from noninfected oysters; ECP LMW = LMW (less than $50 \mathrm{kDa})$ fraction of the ECP.

significant correlation was observed in the intensities of the different bands in our study. Proteolytic band profiles in the plasma of $C$. virginica are similar to profiles of MMPs seen in the plasma of other molluscs (Mannello et al., 2001), marine invertebrates (Iida et al., 1991; Quigley et al., 1993; Robinson, 1997), and even vertebrate species (Massova et al., 1998; Shapiro, 1998; Nagase and Woessner, 1999), indicating that these bands may well correspond to several individual MMPs. Further isolation and characterization of both oyster MMPs and parasitic proteases would provide great insights into their functions, mechanism of regulation, and roles in immune defenses and pathology.

One of the most significant findings of this study is the significant decrease in total protease activity observed in the plasma of oysters collected $24 \mathrm{hr}$ after injection of $P$. marinus into the adductor muscle. This decrease was not observed in the first experimental infection, which did not progress to clinical Dermo disease. This was an unexpected finding because we had also observed a significant increase in total protease activity 4 $\mathrm{hr}$ after injection of the parasite, as well as the appearance of bands of protease activity from parasitic origin, most prevalent $24 \mathrm{hr}$ after injection of the parasite. Interestingly, a significant and transient decrease in the intensity of the oyster's metalloproteinases was observed in the plasma of experimentally infected oysters at early time points after injection of the parasite. One possible explanation to these findings is that $P$. marinus proteases are selectively degrading oyster proteases. Selective degradation of proteins in the plasma of $C$. virginica by Per- kinsus proteases has been reported previously (Oliver et al., 1999). Furthermore, our in vitro experiments show that coincubation of oyster plasma with culture supernatants of $P$. marinus containing parasitic proteases results in the degradation of oyster proteases. Alternatively, the transient decrease in oyster proteases after experimental infection with $P$. marinus could be due to the production of metalloproteinase inhibitors by oyster hemocytes in response to $P$. marinus infection. Although we have not evaluated in this study the levels of metalloproteinase inhibitors in the plasma of experimentally infected oysters, changes in the levels of protease inhibitors in the plasma of bivalves under disease conditions have been observed in the soft-shell clam, Mya arenaria (Elsayed et al., 1999), the Atlantic surfclam, Spisula solidissima (Armstrong and Quigley, 1992), and the oysters C. virginica (Faisal et al., 1998; Oliver et al., 2000) and C. gigas (Faisal et al., 1998; Montagnani et al., 2001; Romestand et al., 2002). It has been hypothesized that protease inhibitors have a role in the ability of the Dermoresistant oyster $C$. gigas to eliminate $P$. marinus (Faisal et al., 1998; Romestand et al., 2002).

It is unclear as to what role MMPs play in the defenses of $C$. virginica against the parasite or how the transient dysregulation of oyster MMPs observed in this study could affect parasitic infection. In molluscs, migration of hemocytes to the site of injury is one of the initial responses to infection or shell damage (Mackin, 1951; Perkins, 1976; Cheng, 1996). MMPs are likely involved in hemocyte migration and repair of the tissue at the site of injury. Dysregulation of MMPs by the par- 


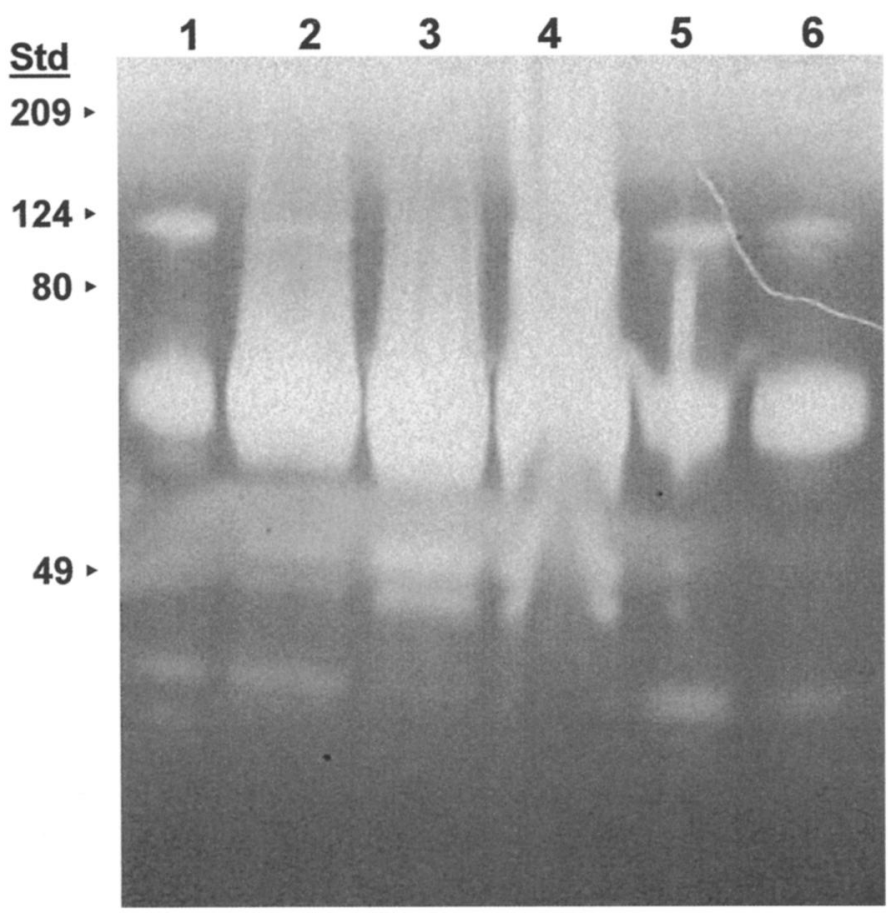

FIGURE 6. Effect of sampling method and source of hemolymph on the patterns of gelatinolytic activity in pools of plasma and hemocyte lysates from naturally infected oysters (Mackin index $=2.3 \pm 1.5$ ). Lane 1, plasma of hemolymph collected from pericardial sinuses by aspiration through notch; lane 2, lysate of hemocytes from hemolymph collected from pericardial sinus by aspiration through notch; lane 3 , lysate of hemocytes from hemolymph collected from the shell cavity of shucked oysters; lane 4, plasma of hemolymph collected from the pericardial sinuses of shucked oysters; lane 5, plasma of hemolymph collected from the shell cavity of shucked oysters; lane 6 , hemocyte lysate of hemolymph collected from the pericardial sinuses of shucked oysters. About $10-15 \mu \mathrm{g}$ protein was loaded per lane.

asite may constitute a virulence mechanism by decreasing the ability of hemocytes to reach the site of injury (Perkins, 1969, 1976; Cheng, 1988; Volety and Fisher, 2000), preventing elimination of the parasite and tissue repair (Mackin, 1951; La Peyre et al., 1995; Bushek et al., 1997; Chintala et al., 2002).

This characterization of the time course of protease activity in the plasma of oysters during the early stages of experimental infection with $P$. marinus highlights the complex interactions occurring between this protozoan parasite and its host, the American oyster $C$. virginica. This research showed that in early stages of experimental infection, there is an increase in the activity of $P$. marinus LMW proteases as well as a transient but significant and rapid (within $24 \mathrm{hr}$ ) decrease in the activity of oyster metalloproteinases. It has been suggested previously based on the observed inability of plasma from oyster species resistant to Dermo disease (C. gigas and Crassostrea arakiensis) to induce $P$. marinus LMW proteases in vitro that the induction of LMW parasitic proteases may be a good indicator of P. marinus susceptibility (MacIntyre et al., 2003). A thorough evaluation of the mechanisms of MMP activity and regulation in response to parasitic infection in both resistant and susceptible species of oysters could determine if the activity of LMW parasitic proteases or MMPs could be used as early indicators of disease and provide insights into the role of prote- ases and protease inhibitors in the mechanisms of resistance to P. marinus.

\section{ACKNOWLEDGMENTS}

We sincerely thank D. Bushek (Baruch Marine Field Laboratory, University of South Carolina, Columbia, South Carolina) for kindly providing the Perkinsus cell cultures, B. Geib (Dutch Harbor, Rhode Island) for providing oysters, and C. Earnhart (Virginia Institute of Marine Sciences, Gloucester Point, Virginia) for providing Perkinsus ECP. We thank A. MacIntyre, C. Earnhart, and S. Kaattari for stimulating discussions, and T. Dorrington and E. Gauger for critical review of the manuscript. This work was supported by National Sea Grant, Oyster Disease Research Program, through Rhode Island Sea Grant under National Oceanic and Atmospheric Administration (NOAA) grant NA86RG0076. The views expressed in this article are those of the author(s) and do not necessarily reflect the views of NOAA or any of its subagencies. The U.S. Government is authorized to produce and distribute reprints for governmental purposes notwithstanding any copyright notation that may appear hereon.

\section{LITERATURE CITED}

Armstrong, P. B., AND J. P. Quigley. 1992. Humoral immunity: $\alpha_{2}-$ macroglobulin activity in the plasma of mollusks. Veliger 35: 161164.

BRADFORD, M. M. 1976. A rapid and sensitive method for the quantitation of microgram quantities of protein utilizing the principle of protein-dye binding. Analytical Biochemistry 72: 248-254.

Braun-Breton, C., AND D. S. Pereira. 1988. Activation of a Plasmodium falciparum protease correlated with merozoite maturation and erythrocyte invasion. Biology of the Cell 64: 223-231.

Bricelj, V. M., S. E. Ford, F. J. Borrero, F. O. Perkins, G. Rivara, R. E. Hillman, R. A. Elston, And J. Chang. 1992. Unexplained mortalities of hatchery-reared, juvenile oysters, Crassostrea virginica (Gmelin). Journal of Shellfish Research 11: 331-347.

BusheK, D., S. K. Allen, K. A. Alcox, R. G. Gustafson, and S. E. FORD. 1997. Response of Crassostrea virginica to in vitro culture Perkinsus marinus: Preliminary comparisons of three inoculation methods. Journal of Shellfish Research 16: 479-485.

CHENG, T. C. 1988. Strategies employed by parasites of marine bivalves to effect successful establishment in hosts. American Fisheries Society Special Publications 18: 112-129.

1996. Hemocytes: Forms and functions. In The Eastern oyster Crassostrea virginica, V. S. Kennedy, R. I. Newell, and A. E. Eble (eds.). Maryland Sea Grant Program, College Park, Maryland, p. 299-333.

Chintala, M. M., D. Bushek, And S. E. Ford. 2002. Comparison of in vitro-cultured and wild-type Perkinsus marinus. II. Dosing methods and host response. Diseases of Aquatic Organisms 51: 203 216.

Corradin, S., A. Ransijn, G. Corradin, J. Bouvier, M. B. Delgado, J. Fernandez-Carneado, J. C. Mottram, G. Vergeres, and J. MAUEL. 2002. Novel peptide inhibitors of Leishmania gp63 based on the cleavage site of MARCKS-related protein. Biochemistry Journal 367: 761-769.

$\longrightarrow,-,-$ M. A. Roggero, A. A. Schmitz, P. Schneider, J. MAuel, AND G. Vergeres. 1999. MARCKS-related protein (MRP) is a substrate for the Leishmania major surface protease leishmanolysin (gp63). Journal of Biological Chemistry 274: 25411-25418.

DARMON, A. J., AND R. C. Bleackley. 1998. Proteases and cell-mediated cytotoxicity. Critical Reviews in Immunology 18: 255-273.

Druilhe, P., P. Hagan, AND G. A. W. RoOK. 2002. The importance of models of infection in the study of disease resistance. Trends in Microbiology 10: s38-s46.

Dungan, C. F., R. M. Hamilton, E. M. Burreson, and L. M. Ragone Calvo. 1996. Identification of Perkinsus marinus portals of entry by histochemical immunoassays of challenged oysters. Journal of Shellfish Research 15: 500.

Elsayed, E. E., S. M. McLaughlin, And M. Faisal. 1999. Protease inhibitors in plasma of the softshell clam Mya arenaria: Identification and effects of disseminated sarcoma. Comparative Biochem- 
istry and Physiology B: Biochemistry and Molecular Biology 123: 427-435.

Faisal, M., E. A. Macintyre, K. G. Adham, B. D. Tall, M. H. KoTHARY, AND J. F. LA PEYRE. 1998. Evidence for the presence of protease inhibitors in Eastern (Crassostrea virginica) and Pacific (Crassostrea gigas) oysters. Comparative Biochemistry and Physiology B: Biochemistry and Molecular Biology 121: 161-168. , J. L. Oliver, AND S. L. KaAtTari. 1999. Role of proteaseantiprotease interactions in Perkinsus marinus infection in Cras sostrea spp. Bulletin of the European Association of Fish Pathologists 19: 269-276.

, D. Y. Schafhauser, K. A. Garreis, E. Elsayed, and J. F. LA PEYRE. 1999. Isolation and characterization of Perkinsus marinus proteases using bacitracin-sepharose affinity chromatography. Comparative Biochemistry and Physiology B: Biochemistry and Molecular Biology 123: 417-426.

FinesChI, B., AND J. Miller. 1997. Endosomal proteases and antigen processing. Trends in Biochemical Sciences 22: 377-382.

Ford, S. E., M. M. Chintala, AND D. BusheK. 2002. Comparison of in vitro-cultured and wild-type Perkinsus marinus. I. Pathogen virulence. Diseases of Aquatic Organisms 51: 187-201.

, AND M. R. TRIPP. 1996. Diseases and defense mechanisms. In The Eastern oyster, Crassostrea virginica, V. S. Kennedy, R. I. Newell, and A. E. Eble (eds.). Maryland Sea Grant, College Park, Maryland, p. 581-660.

Garreis, K. A., J. F. La Peyre, And M. Faisal. 1996. The effects of Perkinsus marinus extracellular products and purified proteases on oyster defense parameters in vitro. Fish and Shellfish Immunology 6: $581-597$.

Gauthier, J. D., AND G. R. VAsta. 1993. Continuous in vitro culture of the Eastern oyster parasite Perkinsus marinus. Journal of Invertebrate Pathology 62: 321-323.

Heussen, C., AND E. B. DowdLe. 1980. Electrophoretic analysis of plasminogen activators in polyacrylamide gels containing sodium dodecyl sulfate and copolymerized substrates. Analytical Biochemistry 102: 196-202.

IIDA, Y., T. NAKAGAwA, AND F. NAgoyama. 1991. Properties of collagenolytic proteinase in Japanese spiny lobster and horsehair crab Hepatopancreas. Comparative Biochemistry and Physiology B: Biochemistry and Molecular Biology 98: 403-410.

KLembA, M., AND D. E. GoldBerG. 2002. Biological roles of proteases in parasitic protozoa. Annual Reviews in Biochemistry 71: 275305.

La Peyre, J. F., D. Y. Schafhauser, E. H. Rizkalla, and M. Faisal. 1995. Production of serine proteases by the oyster pathogen $\mathrm{Per}$ kinsus marinus (Apicomplexa) in vitro. Journal of Eukaryotic $\mathrm{Mi}-$ crobiology 42: 544-551.

$\longrightarrow$, H. A. YARNALl, AND M. FAISAL. 1996. Contribution of Perkinsus marinus extracellular products in the infection of Eastern oysters (Crassostrea virginica). Journal of Invertebrate Pathology 68 312-313.

Llano, E., A. M. Pendas, P. Aza-Blanc, T. B. Kornberg, and C. LOPEZ-OTIN. 2000. Dm1-MMP, a matrix metalloproteinase from Drosophila with a potential role in extracellular matrix remodeling during neural development. Journal of Biological Chemistry 275: 35978-35985.

Macintyre, E. A., C. G. Earnhart, and S. L. KaAttari. 2003. Host oyster tissue extracts modulate in vitro protease expression and cellular differentiation in the protozoan parasite, Perkinsus marinus. Parasitology 126: 293-302.

MACKIN, J. G. 1951. Histopathology of infection of Crassostrea virginica (Gmelin) by Dermocystidium marinum Mackin, Oven, and Collier. Bulletin of Marine Science of the Gulf and Caribbean 1: 72 87.

1962. Oyster diseases caused by Dermocystidium marinum and other microorganisms in Louisiana. Publications of the Institute of Marine Sciences University of Texas 7: 132-229.

, AND J. L. BoswelL. 1955. The life cycle and relationships of Dermocystidium marinum. Proceedings of the National Shellfisheries Association 46: 112-115.

Mannello, F., L. Canesi, G. Gazzanelli, and G. Gallo. 2001. Biochemical properties of metalloproteinases from the hemolymph of the mussel Mytilus galloprovincialis Lam. Comparative Biochem- istry and Physiology B: Biochemistry and Molecular Biology 128: 507-515.

Marden, P. A., A. K. Tunlid, K. G. Malmcrona-Friberg, G. Odham, AND S. KJELleberG. 1985. Physiological and morphological changes during short term starvation of marine bacteriological isolates. Archives in Microbiology 142: 326-332.

MAREIRO, K. L. 2002. A survey of disease in two commercially important bivalves in Rhode Island (1998-2001). M.S. Thesis. University of Rhode Island, Kingston, Rhode Island, 144 p.

Marsh, A. G., J. D. Gauthier, AND G. R. Vasta. 1995. A semiquantitative PCR assay for assessing Perkinsus marinus infections in the Eastern oyster, Crassostrea virginica. Journal of Parasitology 81: $577-583$.

Martinez, J., And J. J. CAzZulo. 1992. Anomalous electrophoretic behaviour of the major cysteine proteinase (cruzipain) from Trypanosoma cruzi in relation to its apparent molecular mass. FEMS Microbiology Letters 74: 225-229.

Massova, I., L. P. Kotra, R. Fridman, And S. Mobashery. 1998. Matrix metalloproteinases: Structures, evolution, and diversification. FASEB Journal 12: 1075-1095.

McKerrow, J. H., E. Sun, P. J. Rosenthal, And J. Bouvier. 1993. The proteases and pathogenicity of parasitic protozoa. Annual Reviews in Microbiology 47: 821-853.

Mclaughlin, S. M., E. E. Elsayed, and M. Faisal. 2000. Analysis of extracellular proteins of two Perkinsus spp. isolated from the softshell clam Mya arenaria in vitro. Comparative Biochemistry and Physiology B: Biochemistry and Molecular Biology 126: 587-598.

MEZA, I. 2000. Extracellular matrix-induced signaling in Entamoeba histolytica: Its role in invasiveness. Parasitology Today 16: 23-28.

Modha, J., M. C. Roberts, And J. R. Kusel. 1996. Schistosomes and Serpins: A complex business. Parasitology Today 12: 119-121.

Montagnani, C., F. Le Roux, F. Berthe, and J. M. Escoubas. 2001. Cg-TIMP, an inducible tissue inhibitor of metalloproteinase from the Pacific oyster Crassostrea gigas with a potential role in wound healing and defense mechanisms. FEBS Letters 500: 64-70.

NAGASE, H., AND J. F. WOESSNER. 1999. Matrix metalloproteinases. Journal of Biological Chemistry 274: 21491-21494.

Noren, F., O. Moestrup, And A.-S. Rehnstam-Holm. 1999. Parvilucifera infectans Noren et Moestrup gen. et sp. Nov. (Perkinsoa phylum nov.): A parasitic flagellate capable of killing toxic microalgae. European Journal of Protistology 35: 233-254.

Oliver, J. L., P. M. Gaffney, S. K. Allen, M. Faisal, and S. L. KaAtTARI. 2000. Protease inhibitory activity in selectively bred families of Eastern oysters. Journal of Aquatic Animal Health 12: 136-145. , T. D. Lewis, M. Faisal, And S. L. KaAtTARi. 1999. Analysis of the effects of Perkinsus marinus proteases on plasma proteins of the Eastern oyster (Crassostrea virginica) and the Pacific oyster (Crassostrea gigas). Journal of Invertebrate Pathology 74: 173183.

Ordás, M. C., B. Novoa, M. Faisal, S. M. Mclaughlin, and A. FiGUERAS. 2001. Proteolytic activity of cultured Pseudoperkinsus tapetis extracellular products. Comparative Biochemistry and Physiology B: Biochemistry and Molecular Biology 130: 199-206.

OtTinger, C., T. Lewis, D. Shapiro, M. Faisal, and S. L. KaAtTari. 2001. Detection of Perkinsus marinus extracellular proteins in tissues of the Eastern oyster Crassostrea virginica: Potential use in diagnostic assays. Journal of Aquatic Animal Health 13: 133-141.

PERKINS, F. O. 1969. Ultrastructure of vegetative stages in Labyrinthomyxa marina (Dermocystidium marinum), a commercially significant oyster pathogen. Journal of Invertebrate Pathology 13: 199 222

. 1976. Dermocystidium marinum infection in oysters. Marine Fish Review 38: 19-21.

Quigley, J. P., R. S. Braithwaite, And P. B. Armstrong. 1993. Matrix metalloproteases of the developing sea urchin embryo. Differentiation 54: 19-23.

RAY, S. R. 1952. A culture technique for the diagnosis of infection with Dermocystidium marinum, Mackin, Oven, and Colliers in oysters Science 116: $360-361$.

. 1966. A review of the cultured method for detecting Dermocystidium marinum, with suggested modifications and precautions. Proceedings of the National Shellfisheries Association 54: 55-69. 1996. Historical perspective on Perkinsus marinus disease of 
oysters in the Gulf of Mexico. Journal of Shellfish Research 15: 9-11.

RhoAds, M. L., AND R. H. FetTERER. 1997. Extracellular matrix: A tool for defining the extracorporeal function of parasite proteases. Parasitology Today 13: 119-122.

RoBinson, J. J. 1997. Characterization of a metalloproteinase: A late stage specific gelatinase activity in the sea urchin embryo. Journal of Cell Biochemistry 66: 337-345.

Romestand, B., F. CORBIER, AND P. Roch. 2002. Protease inhibitors and haemagglutinins associated with resistance to the protozoan parasite, Perkinsus marinus, in the Pacific oyster, Crassostrea gigas. Parasitology 125: 323-329.

Rosenthal, P. J., K. Kim, J. H. McKerrow, and J. H. Leech. 1987. Identification of three stage-specific proteinases of Plasmodium falciparum. Journal of Experimental Medicine 166: 816-821.

SHAPIRO, S. D. 1998. Matrix metalloproteinase degradation of extracellular matrix: Biological consequences. Current Opinion in Cell Biology 10: 602-608.

SIM, R. B., AND A. LAICH. 2000. Serine proteases of the complement system. Biochemical Society Transactions 28: 545-550.

Tall, B. D., J. F. La Peyre, J. W. Bier, M. D. Miliotis, D. E. Hanes, M. H. Kothary, D. B. Shah, and M. Faisal. 1999. Perkinsus marinus extracellular protease modulates survival of Vibrio vulni- ficus in Eastern oyster (Crassostrea virginica) hemocytes. Applied and Environmental Microbiology 65: 4261-4263.

Thoessen, J. C. 1994. Suggested procedures for the detection and identification of certain finfish and shellfish pathogens, 4th ed. Fish Health Section, American Fisheries Society, Fair Haven, New Jersey, $317 \mathrm{p}$.

Villadangos, J. A., R. A. Bryant, J. Deussing, C. Driessen, A. M Lennon-Dumenil, R. J. Riese, W. Roth, P. Saftig, G. P. Shi, H. A. Chapman, C. Peters, and H. L. Ploegh. 1999. Proteases involved in MHC class II antigen presentation. Immunological Reviews 172: $109-120$.

Volety, A., AND W. S. Fisher. 2000. In vitro killing of Perkinsus mar inus by hemocytes of oysters Crassostrea virginica. Journal of Shellfish Research 19: 827-834.

WadA, K, H. SATO, H. KinOH, M. KaIITA, H. Yamamoto, and M. SEIKI. 1998. Cloning of three Caenorhabditis elegans genes potentially encoding novel matrix metalloproteinases. Gene 211: 57-62.

WindLE, H. J., AND D. KelleHER. 1997. Identification and characterization of a metalloprotease activity from Helicobacter pylori. Infection and Immunity 65: 3132-3137.

Ziegler, G., K. PAynter, AND D. Fisher. 2002. Matrix metalloproteinase-like activity from hemocytes of the Eastern oyster, Crassostrea virginica. Comparative Biochemistry and Physiology B: Biochemistry and Molecular Biology 131: 361-370. 